\title{
Leaders' Emotional Intelligence and Employee Retention: Mediation of Job Satisfaction in the Hospitality Industry
}

\author{
Adel Ali Yassin Alzyoud ${ }^{1}$, Umair Ahmed ${ }^{2}$, Mahmoud Radhwan Hussein AlZgool ${ }^{3}$ \& Munwar Hussain Pahi ${ }^{4}$ \\ ${ }^{1}$ College of Administrative Sciences, Applied Science University (ASU), Bahrain \\ ${ }^{2}$ Arab Open University, Kingdom of Bahrain \\ ${ }^{3}$ College of Administrative and Financial Sciences, Gulf University, Bahrain \\ ${ }^{4}$ Indus University Karachi, Sindh, Pakistan \\ Correspondence: Adel Ali Yassin Alzyoud, College of Administrative Sciences, Applied Science University (ASU), \\ Bahrain.
}

Received: April 20, 2019

Accepted: May 7, 2019

Online Published: May 19, 2019

doi:10.5430/ijfr.v10n3p1

URL: https://doi.org/10.5430/ijfr.v10n3p1

\begin{abstract}
The present study has catered to one of the major issues faced by organizations across the globe, employee retention. Therein, the study attempted to examine the relationship of leaders' emotional intelligence with employee retention. In parallel, the study also tested to underline if job satisfaction could mediate this relationship. Through targeting non-managerial employees working in the four- and five-star hotels in Jordan, the present study sampled 380 employees from the 56 hotels. Through using structural equation modelling approach via Smart PLS 2.0 M3, the present study found significant relationship between leaders' emotional intelligence and employee retention hence suggesting that leaders' emotional awareness and management of employees whilst enriching their emotional expression and skills can significantly help boost employee retention. Accordingly, the study also reported significant mediation of job satisfaction in the relationship between leaders' emotional intelligence and employee retention. The study has reported that leaders' emotional intelligence can induce sense of belongingness leading to enhance job satisfaction which further results in harnessing employee retention. The study forwards notable implications for practice and scope for future studies in light of the findings.
\end{abstract}

Keywords: leadership, emotional intelligence, job satisfaction, employee retention, mediation

\section{Introduction}

Employee retention is a major issue these days across the globe (Mahmood \& Nasir, 2017) particularly in the service-based industries (Msengeti \& Obwogi, 2015) whereby, little is known how to address this issue holistically (Aruna \& Anitha, 2015). Particularly, the hotel industry has been critically underlined facing this issue with little known to help companies resolve these issues (Economies across the globe are facing this issue which costs them millions of dollars in recruitment, training and loosing cycle due to poor retention rates. For example, United Arab Emirates lost 2.7 billion dollars in 2015 because of it (Harhara \& Singh, 2015) and similar figures from other neighboring economies wont surprise. Notably, leaders way of behavior, work and dynamism has been much appreciated recently to help employees retain in the company (e.g., Aruna \& Anitha, 2015; Fulmer \& Ostroff, 2017). Particularly, their emotional intelligence has been much appreciated to help employees show better behaviors and outcomes such as job satisfaction (Miao, Humphrey \& Qian, 2016; Zhu, et.al 2018); team performance (Neil, Wagstaff, Weller \& Lewis, 2016); Creativity (Parke, Seo \& Sherf, 2015) and so on. Accordingly, in the light of employee behaviors and outcomes job satisfaction has been reported to mediate several relationships (e.g., Tongchaiprasit \& Ariyabuddhiphongs, 2016) which underlined an important arena to investigate pertaining to understand and resolve employee retention issues. Therefore, keeping these evidences beforehand, the present study attempted to examine how leaders' emotional intelligence can enhance employee retention thus eliminating this grave concern and to whether or not job satisfaction can mediate.

\subsection{Employee Retention}

Many researchers have addressed the issue of turnover intention (Krishnan \& Singh, 2010 and Mobley, 1982). Meanwhile, some of researchers have studied employee retention dependent variable, calling it either employee 
intentions to stay in the company and deciding not to quite too soon (Mitchell, MacKenzie, Styve \& Gover, 2000). As per Mondy (2012), the term employee retention can be referred as perspective of an organization to retain its employees. Studies have suggested that employee retention is an issue across the globe and majority of the organizational authorities are not aware of how to ensure employee retention (Juhdi, Pa'wan \& Hansaram, 2013). Organizations have diverse perspective about employee retention whereby, there is lack of research pertaining to how top authorities and more importantly individuals on higher positions can contribute towards keeping the people with the business (Eshiteti, Okaka, Maragia, Odera \& Akerele, 2013). The issue of employee retention according to Hwang \& Chang, 2008) requires attention. more importantly, it is essential to understand that when organizations fails to retains its people because if they lose them, they don't just end up wasting resources but also knowledge, skills and expertise critical for organizational performance. Past studies have also mentioned severe reparations of low employee retention e.g., Khilji \& Wang, 2007; Abbasi \& Hollman, 2000; Yoke, et.al 2018).

\subsection{Concept of Leadership}

As Antonakis, Cianciolo and Sternberg (2004) wrote: "Leadership researchers had struggled for most of the last century to put together an integrated, theoretically cohesive view of the nature of leadership." Nevertheless, a better and promising picture of leadership has begun to surface in the last two decades and studies have been revived in a lot of fields that were considered as lacking in the aspect of consistency.

However, an analysis on existing leadership literature reveals that a lot of the study on the initial "behavioral" schools was integrated into "new" research on leadership method (Bryman, 1992). Further, theories of the "new" leadership school, such as charismatic and transformational leadership theory, evidently stressed upon the categories of behaviors (e.g., compelling manners, transactional manners) that envisage leadership efficacy.

\subsection{Need for Emotional Intelligence for Leaders}

The Ability Model of EI presents an appropriate means to examine the reason behind the leaders' necessity for EI by enquiring as to the causes leaders have to be able to (1) recognize, (2) adopt, (3) comprehend, and (4) handle emotions. In relation to this, Caruso, Mayer, and Salovey (2002) claimed that researchers have discovered the fact that the capability of a leader to recognize emotions and feelings in themselves also permits them to precisely discover the emotions of associates and team, to relate the exact emotions, and to make a distinction between sincere and false emotional demonstration. Further, in discussing empathy, it was stated that it is an important element of EI where it involves a person's capability to comprehend and experience other people's feelings or emotions. Empathy aids a leader's social support and positive inter-personal relationships (George, 2000).

Leaders' recognition of emotions can improve cognitive development and judgment-making (George, 2000), and assist leaders to value other people and inspire them by making emotions accessible, adopting various perspectives that facilitate more adaptable arrangement, and encourage them to be more creative, understanding, and have wider thoughts and outlook (Caruso et al., 2002; George, 2000). Additionally, George (2000) revealed that studies have found that those who are in favorable moods are likely to be more positive and have more favorable views and outlook in comparison to those in unfavorable moods, and, the latter moods result in the pessimistic and negative attitude.

Further, leaders' EI has stronger influence on their victory as leaders as well as on the functioning of their group compared to their intelligent ability (Goleman et al., 2002; Yamaguchi, 2018). This empirical proof has depicted the firm connections between emotional intelligence and job execution, the truth of a connection between emotional intelligence and leadership approach, and the requirement to merge emotional intelligence capabilities and aptitude with leadership abilities. In fact, it was Goleman et al. (2002) who presented the connection to the EI-based approach of leadership.

\subsection{Leaders' Emotional Intelligence and Job Satisfaction}

There are many studies that explain the relationship between EI, leaders' EI and employees' job satisfaction. Some of these studies, e.g. by Dong and Howard (2006) indicated that EI impacts employees' job satisfaction positively. Furthermore, Sy, Tram and O'Hara (2006) emphasized that leaders' EI significantly influences employees' job satisfaction with $\Delta R^{2}=.06$ statistical result. Also, Samanvitha and Jawahar (2012) asserted that EI has a positive relationship with job satisfaction. This is evidenced when the Beta value obtained by Samanvitha and Jawahar's (2012) study is 0.357. Moreover, Kafetsios and Zampetakis (2008) underlined that EI influences positively on job satisfaction. Their result produced standardised total effects of EI on job satisfaction of 0.49 (95 percent percentile confidence interval: 0.40-0.58, $p<0.01$ ) (Kafetsios \& Zampetakis, 2008). In contrast, Fortner (2013) found that there is insignificant relationship between leader's EI and employees' job satisfaction. This study was conducted in the 
health sector in the USA.

\subsection{Leaders' Emotional Intelligence and Employee Retention}

The productivity in the organization can be affected by employee retention (Rust et al., 1996). Furthermore, Momeni (2009) emphasized that the EI of leaders impacts positively on the outcomes such as improving the performance and decreasing the employees' turnover rates thus, enhancing employee retention. Nonetheless, understanding the recent development on the turnover rate, i.e., employees' turnover intention is considered as one the major problems that are faced among organizations (Frank, Finnegan \& Taylor, 2004). In addition, Vigoda-Gadot and Meisler (2010) demonstrated that EI has a negative relationship with negative outcomes like burnout, negligent behavior, and turnover intention. Meanwhile, Stephens (2007) has emphasized that leaders' EI influences employee turnover intention. Therefore, the following hypothesis was tested:

H1: There will be a positive relationship between Leaders' emotional intelligence and Employee Retention.

\subsection{Relationship Between Job Satisfaction and Employee Retention}

Job satisfaction is considered as one of the significant predictors of employee retention (Mosadeghrad, Ferlie \& Rosenberg, 2008). Furthermore, Griffeth, Hom and Gaertner (2000) and Amah (2009) stated that employees' job satisfaction has direct negative relationship with turnover intention $(-.17, \mathrm{p}<0.01)$. In addition, Goldman and Tabak (2010) indicated that low job satisfaction affects high employees Retention. Additionally, Tian-Foreman (2009) emphasized that job satisfaction is strongly correlated with intention to leave with $\mathrm{r}=0.188$. This result from Tian-Foreman is supported by earlier studies that examined the relationships between job satisfaction and intention to leave by Cotton and Tuttle (1986); Price (2001); Hayes, O’Brien, Duffield, Shamian, Buchan, Hughes, Laschinger, North and Stone (2006) and Shields and Ward (2001). Besides that, another recent study found that there is a significant relationship between job satisfaction and employees' turnover intention in residential youth-caring in the USA (Fein, 2014).

From the discussion, it was found that leaders' EI and organizational commitment significantly impact job satisfaction, and in addition, job satisfaction significantly affects employees' turnover intention. Hence, this study assumes that job satisfaction has a positive character as mediating variable that has influence in this framework. Looking at the significant influence of leaders' EI and organizational commitment on job satisfaction and the significant influence of job satisfaction on employees' turnover intention, job satisfaction will be focused on as a mediator in this research study in the Jordanian hotel industry. Therefore, this study comes out with the following hypotheses:

\subsection{Job Satisfaction as the Mediating Variable}

Experimental studies in psychology seldom involve both operation of the mediator and measurement of mediating variables. Fiske, Kenny, and Taylor (1982) demonstrated that the mediation can be investigated statistically if a research study includes measures of a mediating variable as well as the independent and dependent variable. Meaning that, the mediation analysis can be suitable method to increase an in knowledge can be obtained from a research study when measures of the mediating process are available. Hence, it is not necessary for this study to conduct an experimental study to investigate the mediating role of job satisfaction. Therefore, this study relies on Baron and Kenny (1986) in testing the mediating variable. They indicated that to test the mediation effect, the mediator should be regressed with the independent variable IV, while the dependent variable DV should be regressed with the IV, and the DV should be regressed with the IV and the mediator.

H2: Job satisfaction will mediate the relationship between leaders' emotional intelligence and employee retention.

\section{Research Methodology}

\subsection{Instrumentation and Operationalization of Constructs}

For the case of employee retention, the present study adapted the scale by Kyndt et al. (2009) with regards to Haskins (2008)'s instrument was used to assess leaders' emotional intelligence whereby, Minnesota Satisfaction Questionnaire (MSQ) was deployed to research the mediation of job satisfaction in the relationship between leaders' emotional intelligence and employee retention (Weiss, Dawis, England \& Lofquist, 1967). Respondents were required to respond through 5-point likert scale. 


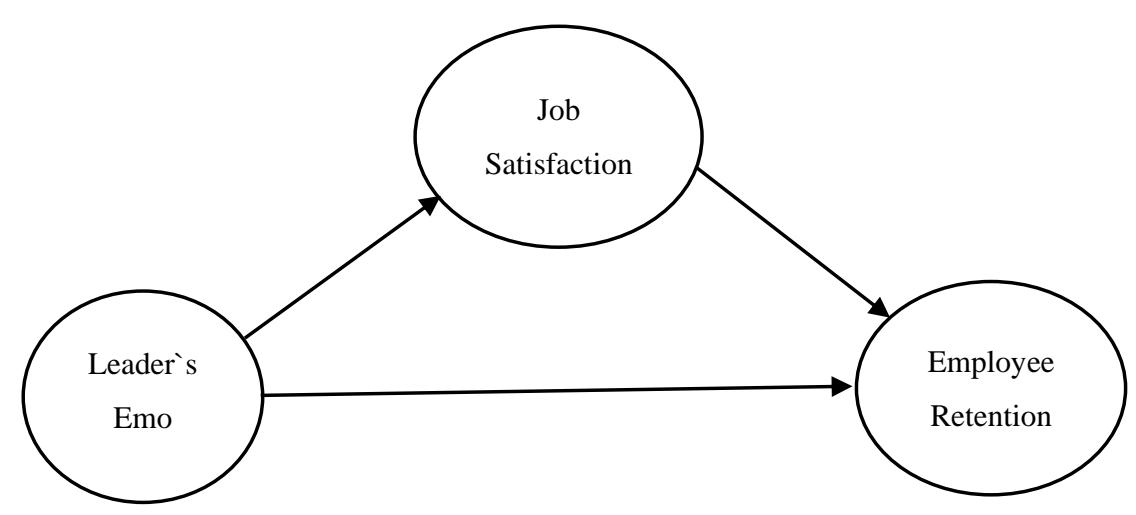

Figure 1. Conceptual framework

\subsection{Methodology}

\subsubsection{Sample}

Non-managerial employees working in the Four- and Five-Star hotels in Jordan were sampled for this study. The operational employees in five-star and four-star hotels include employees who work in front office, food production, food \& beverage service, and housekeeping department. Accordingly, the operational employees in five-star and four-star hotels were chosen instead of the managerial employees due issues with regards to employee retention (Al-Ababneh \& Lockwood, 2010). Hotel industry was chosen due to the fact that it contributes heavily towards the gross national income of the country. These operation-level employees were selected by using the disproportionate stratified random sampling technique because this technique is more efficient to cater to large sample. The disproportionate stratified random sampling technique was conducted to select the respondents on the basis of 56 of hotels divided into 45 strata of hotels due to merging all the branches of the same hotels' brands (four-star and five-star hotels). Therein, for a total of 10788 employee, krejcie and Morgan (1970)'s table underlined a minimum sample of 380 .

\section{Data Analysis and Findings}

\subsection{Assessment of Measurement Model}

Prior to examining the hypothesized relationships, the study assessed the individual item reliability via ensuring loading greater than or equal to 0.5 ; internal consistency through ensuring composite reliability scores above 0.7 and convergent validity through confirming average variance extracted to be 0.5 or above as per the recommendations of Hair et al. (2013). Therein, the individual item loadings ranged between 0.54 to 0.90 and CR scores between 0.87 and 0.95 . Overall, 13 items from leaders' emotional intelligence scale and 7 items from job satisfaction scale were retained after deleting lower loading items. Table 2 provides more details in this regard.

Table 1. Measurement model

\begin{tabular}{llllll}
\hline latent variable & items & loadings & AVE & CR & R-square \\
\hline Job Satisfaction: & & & 0.505 & 0.877 & 0.389 \\
\hline & JS1 & 0.701 & & & \\
\hline JS10 & 0.7033 & & & \\
\hline JS11 & 0.699 & & & \\
\hline JS2 & 0.771 & & \\
\hline JS3 & 0.733 & & \\
\hline JS5 & 0.634 & & & \\
\hline
\end{tabular}




\begin{tabular}{|c|c|c|c|c|c|}
\hline \multirow{2}{*}{ Leader's Emotional Intelligence } & JS9 & 0.726 & & & \\
\hline & & & 0.606 & 0.951 & 0.571 \\
\hline & LEI1 & 0.502 & & & \\
\hline & LEI2 & 0.752 & & & \\
\hline & LEI3 & 0.650 & & & \\
\hline & LEI15 & 0.646 & & & \\
\hline & LEI16 & 0.763 & & & \\
\hline & LEI17 & 0.883 & & & \\
\hline & LEI18 & 0.900 & & & \\
\hline & LEI11 & 0.840 & & & \\
\hline & LEI12 & 0.877 & & & \\
\hline & LEI13 & 0.545 & & & \\
\hline & LEI6 & 0.890 & & & \\
\hline & LEI8 & 0.818 & & & \\
\hline & LEI9 & 0.905 & & & \\
\hline Employee Retention & & & 0.659 & 0.927 & \\
\hline & ER1 & 0.680 & & & \\
\hline & ER2 & 0.866 & & & \\
\hline & ER3 & 0.864 & & & \\
\hline & ER4 & 0.780 & & & \\
\hline & ER5 & 0.828 & & & \\
\hline & ER6 & 0.700 & & & \\
\hline & ER7 & 0.865 & & & \\
\hline & ER9 & 0.892 & & & \\
\hline
\end{tabular}

Accordingly, discriminant validity was ensured based on the recommendations of Fornell and Larcker (1981) whereby, the square root of AVE scores is required to be greater than the compared values in the cross loadings table. Table 2 provides further details in this regard.

Table 2. Discriminant validity

\begin{tabular}{llll}
\hline & JS & LEI & ER \\
\hline Job Satisfaction: & $\mathbf{0 . 7 1 1}$ & & \\
\hline Leader's Emotional Intelligence & 0.623 & $\mathbf{0 . 7 7 8}$ & \\
\hline Employee Retention & 0.665 & 0.695 & $\mathbf{0 . 7 7 2}$ \\
\hline
\end{tabular}

\subsection{Structural Model Assessment}

Following the confirmation of the psychometric properties of the conceptualized framework, the study examined the structural model whereby, level of significance of the hypothesized relationships was assessed. Through deploying bootstrapping procedures, 500 bootstraps were applied to test the significance of the path coefficients. The proposal 
resulted in significant relationship between leaders' emotional intelligence and turnover intention $(\beta=0.686 ; \mathrm{t}=14.845)$ hence supporting hypothesis 1 . Accordingly, the study also found significant mediation of job satisfaction between leaders' emotional intelligence and turnover intention $(\beta=0.713 ; \mathrm{t}=4.826)$ at $95 \%$ confidence level thus, landing support to hypothesis 2 as well. Table 3 provides further details in this regard.

Table 3. Results

\begin{tabular}{llllllc}
\hline Hypothesis & Relationship & Beta & Standard Error & T-Value & 95\% LL & 95\% UL \\
\hline H1 & LEI -> ER & 0.686 & 0.0462 & 14.845 & & \\
\hline H2 & LEI -> JS-> ER & $\mathbf{0 . 7 1 3}$ & $\mathbf{0 . 0 4 9}$ & $\mathbf{4 . 8 2 6}$ & $\mathbf{0 . 1 4}$ & $\mathbf{0 . 3 3 3}$ \\
\hline
\end{tabular}

\section{Discussion}

The present study attempted to examine the relationship between leaders' emotional intelligence and turnover intention followed by the mediation of job satisfaction in this relationship. The findings have underlined notable role and contribution of leaders' emotional sensibility and competence at work towards facilitating employee to overcome their issues that could potentially lead them towards quitting. The findings have helped us understand that employees at the workplace need people in the position of authority to be emotionally talented to handle work situations and tempting issues in order to provide subordinates a better working environment, thus resulting in pushing them to stay with the organization. The findings are parallel to the scholarly assertions of Momeni (2009) outlining the notable contribution of leaders' emotional intelligence and its impact on employee retention. There is a need to understand that leaders' competence in recognizing the emotional aspects of the individual subordinates and working to uncover their feelings to help empathize.

Accordingly, the findings have also outlined that the ability of a leader to recognize the emotions can significantly help improve the overall judgement and decision making. In addition, it can also help people to gain inspiration to become more creative in the work environment thus enhancing behaviors and outcomes. The findings have also landed support to the empirical outcomes of Goleman et al. (2002) which suggested that leaders' strong or positive emotional intelligence can help them to be responsively effective in functioning well in the organization and motivating people to give the desired outcomes.

Accordingly, the current study also found mediation of job satisfaction in the relationship between leaders' emotional intelligence and employee retention. This suggests that when leaders are emotionally intelligent, they facilitate their subordinates well whilst keeping their feelings at work intact which enables them to boost their satisfaction with the jobs which leads them to retain with the company. In other words, the findings suggest that in order to retain employees, leaders should work on capitalizing their emotional intelligence in order to enhance employees' job satisfaction to result in employee retention. The finding has underlined that making employees to remain with the organization, it is essential that they work to connect their satisfaction with leaders' emotional intelligence. This also suggests that employees who are satisfied with their job tend to be in a better position to capitalize upon leaders' emotional intelligence to enhance retention. Henceforth, job satisfaction is a critical prospect for organizations and researchers for boosting employee retention.

\subsection{Implications}

Several implications can be drawn from the present study. On a practical note, the results forward implications for the leaders and people managing people to work on being emotionally intelligent. Therein, the findings assert leaders to look into prospects that could help them understand emotions, the art of understanding individual and employees' emotions and working with a creative approach to make work environment more productive and satisfactory. Training interventions (Cherniss \& Adler, 2000) could be of great help in this regard to educate and learn on this for people in leadership roles. In parallel, the implications for practice also underline that emotionally intelligent leaders will obtain more resource and facilitation to the help employees (subordinates) experience a sense of belongingness at work which will result in further promising outcomes for the business. Similarly, the findings imply for general management to look into the aspect of job satisfaction to ensure employee retain. In simple, organizations need to look at prospects alongside leaders' emotional intelligence to boost their satisfaction with the jobs so that they stay in the organization for longer such as revising compensation (e.g., Lee \& Wilbur, 1985); training (Schmidt, 2007; Wonyra,2018); colleagues at work (Ducharme \& Martin, 2000; Zhu \& Chen 2018) and so on. Referring back to leaders, apart from emotional intelligence, they can also look into their style of leadership as some like 
Transformational style of leadership has been reported to be highly significant in predicting job satisfaction (Hanaysha et al., 2012; Medley \& Larochelle, 1995) thus furthering employee retention.

\subsection{Limitations and Scope for Further Studies}

Despite notable contributions, the present study has some limitations to be highlighted as well. At first, the present study attempted to examine the relationship between leaders' emotional intelligence and employee retention followed by the mediation of job satisfaction with a cross sectional approach thus limiting the causal references. Therefore, future studies may investigate examining these relationships with a longitudinal approach. Accordingly, the present study only examined the framework across the hotel industry in Jordan hence, future studies may look into testing similar framework in other occupation settings. Likewise, there is a room for further enhancing the framework via incorporating more independent variables to study their relationship with employee retention in a mediated model. Pertaining to leaders, several other factors such as personality, style of leadership and individual values may also be taken into consideration to see how they relate with job satisfaction and employee retention.

Likewise, there are several studies testing the moderation of different variables which could also be taken as a $\mathrm{n}$ avenue for further research to see what buffering impact some of the variables can make on these relationships to help better understand the issue of employee retention and its effective resolution.

\section{Conclusion}

In conclusion, the present attempted to examine the role of leaders' emotional intelligence towards employee retention. The Study also tested the mediation of job satisfaction in this relationship and found significant intervention results. The study has concluded that leaders' emotional intelligence is vital to retain employees whereby, job satisfaction mediates this relationship across service staff in the hotel industry of Jordan.

\section{References}

Abbasi, S. M., \& Hollman, K. W. (2000). Turnover: The real bottom line. Public Personnel Management, 29(3), 333-342. https://doi.org/10.1177/009102600002900303

Al-Ababneh, M., \& Lockwood, A. J. (2010, October 25-28). The influence of managerial leadership style on employee satisfaction in Jordanian resort hotels. Paper presented at the EuroCHRIE Annual Research Conference. Amsterdam.

Antonakis, J., Cianciolo, A.T., \& Sternberg, R.J. (2004). The nature of leadership. Sage Publications, Inc.

Aruna, M., \& Anitha, J. (2015). Employee retention enablers: Generation Y employees. SCMS Journal of Indian Management, 12(3), 94-103.

Baron, R. M., \& Kenny, D. A. (1986). The moderator-mediator variable distinction in social psychological research: Conceptual, strategic, and statistical considerations. Journal of Personality and Social Psychology, 51(6), 1173-1182. https://doi.org/10.1037/0022-3514.51.6.1173

Bryman, A. (1992). Charisma and leadership in organizations. Sage, London.

Caruso, D. R., Mayer, J. D., \& Salovey, P. (2002). Relation of an ability measure of emotional intelligence to personality. Journal of Personality Assessment, 79(2), 306-320. https://doi.org/10.1207/S15327752JPA7902_12

Cherniss, C., \& Adler, M. (2000). Promoting emotional intelligence in organizations: Make training in emotional intelligence effective. American Society for Training and Development.

Cotton, J., \& Tuttle, J. (1986). Employee turnover: a meta-analysis and review with implication for research. Academy of Management Review, 11(1), 55-70. https://doi.org/10.5465/amr.1986.4282625

Dong, Q., \& Howard, T. (2006). Emotional intelligence, trust, and job satisfaction. Competition Forum. American Society for Cmopetitiveness, 4(2), 381-388.

Ducharme, L. J., \& Martin, J. K. (2000). Unrewarding work, coworker support, and job satisfaction: A test of the buffering hypothesis. Work and Occupations, 27(2), 223-243. https://doi.org/10.1177/0730888400027002005

Eshiteti, S. N., Okaka, O., Maragia, S. N., Odera, O., \& Akerele, E. K. (2013). Effects of succession planning programs on staff retention. Mediterranean Journal of Social Sciences, 4(6), 157-162. https://doi.org/10.5901/mjss.2013.v4n6p157

Fein, E. (2014). Individual and systemic factors that contribute to job satisfaction and intention to turnover in residential youth-care workers (Order No. 3624539). ProQuest Dissertations \& Theses Global (1553436132). 
Fiske, S. T., Kenny, D. A., \& Taylor, S. E. (1982). Structural models for the mediation of salience effects on attribution. Journal of Experimental Social Psychology, 18(2), 105-127. https://doi.org/10.1016/0022-1031(82)90046-4

Fornell, C., \& Larcker, D. F. (1981, February). Evaluating structural equation models with unobservable variables and measurement error. Journal of Marketing Research, 18, 39-50. https://doi.org/10.1177/002224378101800104

Fortner, A. N. (2013). The role of a leader's emotional intelligence and how it relates to employees' motivation and job satisfaction. Doctoral dissertation, Capella University.

Frank, F. D., Finnegan, R. P., \& Taylor, C. R. (2004). The race for talent: Retaining and engaging workers in the 21st century. Human Resource Planning, 27(3), 12-25.

Fulmer, C. A., \& Ostroff, C. (2017). Trust in direct leaders and top leaders: A trickle-up model. Journal of Applied Psychology, 102(4), 648. https://doi.org/10.1037/ap10000189

George, J. M. (2000). Emotions and leadership: The role of emotional intelligence. Human Relations, 53(8), 1027-1055. https://doi.org/10.1177/0018726700538001

Goldman, A., \& Tabak, N. (2010). Perception of ethical climate and its relationship to nurses' demographic characteristics and job satisfaction. Nursing Ethics, 17(2), 233-246. https://doi.org/10.1177/0969733009352048

Goleman, D., Boyatzis, R. E., \& McKee, A. (2002). Primal leadership: Realizing the power of emotional intelligence. Harvard Business Press.

Griffeth, R. W., Hom, P. W., \& Gaertner, S. (2000). A meta-analysis of antecedents and correlates of employee turnover: update, moderator tests, and research implications for the next millennium. Journal of Management, 26(3), 463-488. https://doi.org/10.1177/014920630002600305

Hair, J. F., Ringle, C. M., \& Sarstedt, M. (2013). Partial least squares structural equation modeling: Rigorous applications, better results and higher acceptance. Long Range Planning, 46(1-2), 1-12. https://doi.org/10.1016/j.lrp.2013.01.001

Hanaysha, J. R., Khalid, K., Mat, N. K., Sarassina, F., Rahman, M. Y., \& Zakaria, A. S. (2012). Transformational leadership and job satisfaction. American Journal of Economics, 2(4), 145-148. https://doi.org/10.5923/j.economics.20120001.32

Harhara, A. S., Singh, S. K., \& Hussain, M. (2015). Correlates of employee turnover intentions in oil and gas industry in the UAE. International Journal of Organizational Analysis, 23(3), 493-504. https://doi.org/10.1108/IJOA-11-2014-0821

Haskins, H. E. M. L. (2008). The role of emotional intelligence in leading a diverse nursing team. Master Thesis, University of South Africa.

Hayes, L. J., O’Brien-Pallas, L., Duffield, C., Shamian, J., Buchan, J., Hughes, F., ... Stone, P. W. (2006). Nurse turnover: a literature review. International Journal of Nursing Studies, 43(2), 237-236. https://doi.org/10.1016/j.ijnurstu.2005.02.007

Juhdi, N., Pa'wan, F., \& Hansaram, R. M. K. (2013). HR practices and turnover intention: the mediating roles of organizational commitment and organizational engagement in a selected region in Malaysia. The International Journal of Human Resource Management, 24(15), 3002-3019. https://doi.org/10.1080/09585192.2013.763841

Kafetsios, K., \& Zampetakis, L. A. (2008). Emotional intelligence and job satisfaction: Testing the mediatory role of positive and negative affect at work. Personality \& Individual Differences, 44(3), 710-720. https://doi.org/10.1016/j.paid.2007.10.004

Khilji, S., \& Wang, X. (2006), Intended and implemented HRM: The missing lynchpin in strategic human resource management. The International Journal of Human Resource Management, 17(7), 1171-1189. https://doi.org/10.1080/09585190600756384

Krejcie, R. V., \& Morgan, D. W. (1970). Determining sample size for research activities. Educational and Psychological Measurement, 30(3), 607-610. https://doi.org/10.1177/001316447003000308

Krishnan, S. K., \& Singh, M. (2010). Outcomes of intention to quit of Indian IT professionals. Human Resource Management: Published in Cooperation with the School of Business Administration. The University of Michigan and in alliance with the Society of Human Resources Management, 49(3), 421-437. 
https://doi.org/10.1002/hrm.20357

Kyndt, E., Dochy, F., Michielsen, M., \& Moeyaert, B. (2009). Employee retention: Organisational and personal perspectives. Vocations and Learning, 2(3), 195-215. https://doi.org/10.1007/s12186-009-9024-7

Lambert, E. G. (2006). I want to leave: A test of a model of turnover intent among correctional staff. Applied Psychology in Criminal Justice, 2(1), 57-83.

Lee, R., \& Wilbur, E. R. (1985). Age, education, job tenure, salary, job characteristics, and job satisfaction: A multivariate analysis. Human Relations, 38(8), 781-791. https://doi.org/10.1177/001872678503800806

Mahmood, N. H. N., \& Nasir, N. S. M. (2017, October). Educational Organization Concerns About Employee Retention Issues. In E-Proceedings (p. 23).

Medley, F., \& Larochelle, D. R. (1995). Transformational leadership and job satisfaction. Nursing Management, 26(9), 64JJ. https://doi.org/10.1097/00006247-199509000-00017

Miao, C., Humphrey, R. H., \& Qian, S. (2016). Leader emotional intelligence and subordinate job satisfaction: A meta-analysis of main, mediator, and moderator effects. Personality and Individual Differences, 102, 13-24. https://doi.org/10.1016/j.paid.2016.06.056

Mitchell, O., Mackenzie, D. L., Styve, G. J., \& Gover, A. R. (2000). The impact of individual, organizational, and environmental attributes on voluntary turnover among juvenile correctional staff members. Justice Quarterly, 17(2), 333-357. https://doi.org/10.1080/07418820000096351

Mobley, W. H. (1982). Employee turnover: Causes, consequences, and control. Addison-Wesley.

Momeni, N. (2009). The Relation Between Managers' Emotional Intelligence and the Organizational Climate They Create. Public Personnel Management, 38(2), 35-48. https://doi.org/10.1177/009102600903800203

Mondy, R. W. (2012). Human resources management. New Jersey: Pearson Education, Inc.

Mosadeghrad, A. M., Ferlie, E., \& Rosenberg, D. (2008). A study of the relationship between job satisfaction, organizational commitment and turnover intention among hospital employees. Health Services Management Research, 21(4), 211-227. https://doi.org/10.1258/hsmr.2007.007015

Msengeti, D. M., \& Obwogi, J. (2015). Effects of Pay and Work Environment on Employee Retention: A Study of Hotel Industry in Mombasa County.

Neil, R., Wagstaff, C. R., Weller, E., \& Lewis, R. (2016). Leader behaviour, emotional intelligence, and team performance at a UK government executive agency during organizational change. Journal of Change Management, 16(2), 97-122. https://doi.org/10.1080/14697017.2015.1134624

Parke, M. R., Seo, M. G., \& Sherf, E. N. (2015). Regulating and facilitating: The role of emotional intelligence in maintaining and using positive affect for creativity. Journal of Applied Psychology, $100(3), 917$. https://doi.org/10.1037/a0038452

Price, J. L. (1977). The Study of Turnover. Paper presented at the Ames. IA: Iowa State University Press.

Price, J. L. (2001). Reflections on the determinants of voluntary turnover. International Journal of Manpower, 22(7), 600-624. https://doi.org/10.1108/EUM0000000006233

Rust, R. T., Stewart, G. L., Miller, H., \& Pielack, D. (1996). The satisfaction and retention of frontline employees: A customer satisfaction measurement approach. International Journal of Service Industry Management, 7(5), 62-80. https://doi.org/10.1108/09564239610149966

Samanvitha, S., \& Jawahar, P. D. (2012). Emotional Intelligence as a Predictor of Job Satisfaction: A Study Amongst Faculty in India. IUP Journal of Management Research, 11(1), 7-28.

Schmidt, S. W. (2007). The relationship between satisfaction with workplace training and overall job satisfaction. Human Resource Development Quarterly, 18(4), 481-498. https://doi.org/10.1002/hrdq.1216

Shields, M. A., \& Ward, M. (2001). Improving nurse retention in the National Health Service in England: the impact of job satisfaction on intentions to quit. Journal of Health Economics, 20(5), 677-701. https://doi.org/10.1016/S0167-6296(01)00092-3

Stephens, B. W. (2007). A phenomenological study: Human resource professionals perceptions of leader emotional intelligence and employee affective commitment. Doctoral dissertation, University of Phoenix.

Sy, T., Tram, S., \& O’Hara, L. A. (2006). Relation of employee and manager emotional intelligence to job 
satisfaction and performance. Journal of Vocational Behavior, 68(3), 461-473. https://doi.org/10.1016/j.jvb.2005.10.003

Tian-Foreman, W. (2009). Job satisfaction and turnover in the Chinese retail industry. Chinese Management Studies, 3(4), 356-378. https://doi.org/10.1108/17506140911007503

Tongchaiprasit, P., \& Ariyabuddhiphongs, V. (2016). Creativity and turnover intention among hotel chefs: The mediating effects of job satisfaction and job stress. International Journal of Hospitality Management, 55, 33-40. https://doi.org/10.1016/j.ijhm.2016.02.009

Vigoda-Gadot, E., \& Meisler, G. (2010). Emotions in management and the management of emotions: The impact of emotional intelligence and organizational politics on public sector employees. Public Administration Review, 70(1), 72-86. https://doi.org/10.1111/j.1540-6210.2009.02112.x

Weiss, D. J., \& Dawis, R. V. England, G. W., \& Lofquist, L. H. (1967). Manual for the Minnesota Satisfaction Questionnaire, 22, 31-35. https://doi.org/10.1037/t05540-000

Wonyra, K. O. (2018). Industrialization and Economic Growth in Sub-Saharan Africa: The Role of Human Capital in Structural Transformation. Journal of Empirical Studies, 5(1), 45-54. https://doi.org/10.18488/journal.66.2018.51.45.54

Yamaguchi, M. (2018). Are Foreign Banks in China Homogenous?: Classification of their Business Patterns. Journal of Accounting, Business and Finance Research, 3(1), 10-17. https://doi.org/10.20448/2002.31.10.17

Yoke, C. C., Mun, Y. W., Peng, L. M., \& Yean, U. L. (2018). Purchase Intention of Residential Property in Greater Kuala Lumpur, Malaysia. International Journal of Asian Social Science, 8(8), 580-590. https://doi.org/10.18488/journal.1.2018.88.580.590

Zafarullah, M. (2018). Impact of VAT on UAE Economy. Asian Development Policy Review, 6(1), 41-49. https://doi.org/10.18488/journal.107.2018.61.41.49

Zhu, C., \& Chen, L. (2018). The impact of macroprudential supervision on the capital operation of commercial banks. Journal of Accounting, Business and Finance Research, 3(2), 56-63. https://doi.org/10.20448/2002.32.56.63

Zhu, Y., Ge, J., Wang, X., \& Xu, Z. (2018). Feature Analysis of Ship Emission Under China's ECA Policy: A Perspective from Shanghai. International Journal of Management and Sustainability, 7(3), 143-155. https://doi.org/10.18488/journal.11.2018.73.143.155 